\title{
Genealogy of an imperial and nationalistic Order
}

The IODE began as it would continue: on a footing of attack and defence, amid a climate of patriotism fuelled by the South Africa War (18991901). Margaret Clark Murray, a sometime journalist, philanthropist and wife of an influential McGill professor, returned to Montreal from London, where she had experienced much pro-war jingoism, and decided to act on the public outpourings of Anglo-Canadian patriotism that she sensed around her. Her intentions were to seek an opportunity to strengthen Canadian national ties as well as imperial connections, her imperialist outlook stemming, in part, from her upbringing in Scotland. Murray had ambitious plans to form an empire-wide Federation of Daughters of the British Empire and Children of the Empire. She would start the organization in Canada, where she resided, and fan outwards to the other parts of the Empire, including Britain.

After a period of fervent writing of national histories, scholars are now exploring the connections, tensions and ironies between national and imperial identities. Benedict Anderson's work has been instrumental in destabilizing the absolute power ascribed to empires by suggesting that they were 'imagined'. Anderson has drawn attention to cases of colonized peoples 'who have every reason to feel hatred for their imperialist rulers' instead being inspired by the power of patriotism and racism to 'love and often profoundly self-sacrificing love'. ${ }^{1}$ In the case of the formation of the IODE, it was Anglo-Celtic 'colonials' who did not feel hatred for their rulers, as they were 'white settlers', attempting to create a 'British' Canada. In this vein Clark Murray's gutsy enthusiasm was simultaneously nationalistic and imperial. She began her task by methodically sending out telegrams to the mayor of the capital city of each province, asking them to call together women to form regional chapters of her proposed organization. She asserted that it was time to 'stand by our Queen at all costs, to shake our fists if necessary, in the 
face of the whole of Europe, and show them what we are made of ${ }^{2}{ }^{2}$ A contemporary member explains the IODE's patriotism: 'It all made perfect sense in 1900 . We are a patriotic organization who love Canada and are patriotic to Canada. We have been accused for years of being patriotic to Britain, which is not true. It's always been a Canadian organization'. ${ }^{3}$ In recalling 1900, she evokes the co-dependence of national and imperial identities, and the need for Canadian nationalism to grow out of an imperial attachment. This, indeed, is the essence of Carl Berger's work on how Anglo-Canada gained a 'sense of power'. Along with Berger's blindness to the IODE in his work on Canada and the South Africa War, Carman Miller similarly finds little place for the IODE's initial work or sentiments. ${ }^{5}$ Yet, as Julia Bush's work on Edwardian ladies and imperial power argues, a 'spiritual creed of Empire was as attractive to many British women as it was to their male

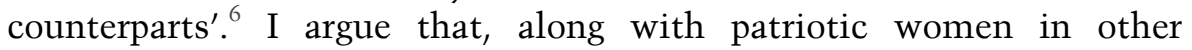
countries, such as the members of the Victoria League and of the South African Guild of Loyal Women, the women of the IODE displayed their own enthusiastic patriotism. As Clark Murray declared: 'do not forget that the destiny of our Empire lies in the hands of our women and our children, more than in politics and in parliaments'. ${ }^{7}$ Thus, Clark Murray and other patriotic women around the British Empire expressed a female imperialism, that placed great importance in, and was justified by, an appeal to women's perceived maternal capabilities.

\section{Patriotic clubs and imperialism}

In its activities, initial class composition and political affiliations, the IODE fitted very closely with the imperial propaganda clubs, a number of which were founded at the end of the nineteenth century in Canada and other parts of the Empire. ${ }^{8}$ These were conservative movements that sought to foster imperial patriotism. Utilizing textbooks, exhibitions and entertainments to promote their ideas, their varied constitutions and their defensive and cultural concerns all came together in the theme of imperial unity. 'The Navy League, the Victoria League, and the Girl and Boy Scout Movements epitomised such organizations. The IODE was clearly a part of this historical moment, enjoying strong links to imperial defence and collaboration with the Navy League. ${ }^{10}$ The symbols of the IODE's organization also reflected empire unity. The motto was 'one flag (the Union Jack), one throne (the British Monarchy), one Empire (the British Empire)'. Likewise, the badge cast imperial foundations in metal, with the crown symbolizing the British monarchy, the Union Jack for 
Britain and the Empire, surrounded by a seven-pointed outward-radiating star, one point for each of the major territories of the Empire.

Clark Murray's way of going about organizing her Order involved tapping into an elite network of individuals representative of the Canadian establishment, her connections spanning outwards from affluent Anglo-Celtic Montreal society. Fredericton was the first place to assemble a group of women at a meeting, on 15 January 1900, where the mayor read Clark Murray's telegram: 'Will the women of Fredericton unite with the women of Montreal in federating as "Daughters of the Empire" and inviting the women of Australia and New Zealand to unite with them in sending to the Queen an expression of our devotion to the Empire and an emergency war fund to be expended as Her Majesty shall deem fit? ${ }^{11}$ As well as involving Britain's antipodean Empire in unity, Clark Murray's empire-wide ambitions included plans to set up an imperial chapter in London as soon as possible. ${ }^{12}$ That ambition, however, tested the limits of 'Empire unity' for a Britain that still considered itself the superior core of that Empire. Clark Murray's ambitions of empire-wide membership were soon crushed, blocked by the rival British women's patriotic organization, formed in 1901 and taking its name from the matriarch of imperialism herself, the Victoria League.

With an aim similar to the IODE's, of promoting closer union between British subjects living in different parts of the Empire, the Victoria League took strong objection to Clark Murray's plans for an imperial chapter of her organization in London, seeing the Canadian counterpart as competition. In a letter to Canada, the Victoria League demanded that Clark Murray hand over to them the contacts that she had made in London. Much to Clark Murray's dismay, self-interested and perhaps meek Toronto members sided with the Victoria League, took 'Federation' out of the name, and made Toronto the national centre of a re-named Imperial Order Daughters of the Empire. ${ }^{13}$ Clark Murray's health suffered, and it was a long time before the deeply upsetting events of formation were smoothed over and she came to be celebrated as the IODE's foundress.

Out of such beginnings, the IODE has itself often treated other women's organizations as the competition. While there has been considerable cooperation between the IODE and other organizaions, especially during wartime, the Order has attempted to maintain control over the activities that it has chosen to participate in. But being considered inferior by the Victoria League and the SOSBW is a theme that recurs through this book. The clashes over control and respect highlight the unique position of the IODE, as a Canadian organization that promoted imperial ideals. While it was staunch in voicing its 
opposition to other Canadian women's organizations, when it came to groups based in Britain the IODE always deferred - indeed such were the hierarchies of the Empire that it had no choice but to fall in with the intentions of the Victoria League and the SOSBW. Here the IODE was trapped by the reverence in which it held all things British.

Clark Murray envisioned a large international membership eventually, to be run along fairly egalitarian lines. In a written retrospective she held that she had founded her 'Daughters on a new principle, namely, to prove what could be done without asking for high patronage', but capitulated when those working with her demanded a patroness. ${ }^{14}$ Known for her own patriotic and charitable work, Lady Minto became the first honorary president. The first president of the IODE, from 1901 to 1910, was Edith Nordheimer. A well-connected member of the Canadian upper-classes, Nordheimer set the standard for presidents to come. As Margaret Gillett's work on Edith Nordheimer reveals, her grandfather, D'Arcy Boulton, was attorney-general of Upper Canada, an uncle was governor-general of Nova Scotia and later governor of Ceylon, while her father, James Boulton, was a well-established barrister. At the age of 24, she married the extremely wealthy 42-yearold businessman Samuel Nordheimer. Moving in elite Toronto circles, Edith Nordheimer was a member of a variety of charitable organizations, from the Working Boys' Home, and the Children's Aid Society, to the Victorian Order of Nurses and the Red Cross Society. ${ }^{15}$ With Edith Nordheimer's presidency came an assurance to the Victoria League that the IODE would not compete for members in Britain or in other places where the Victoria League existed.

Over the course of the twentieth century, the possibility of expansion outside of Canada sporadically re-emerged for the IODE, each time to be met with cold defensive opposition from the Victoria League. With the exception of small and tenuous satellite chapters in preconfederation Newfoundland, the USA, Bermuda, the Bahamas and India, the IODE was restricted to Canada. In the USA the Daughters of the British Empire consisted of a small number of loyal chapters on the eastern seaboard. In common with women involved in Bermuda and the Bahamas, they were largely British ex-patriates. ${ }^{16}$ Alternatively, in India in 1905 Miss Susie Sorabji, a Parsee Christian teacher, organized the Kaiser-I-Hind Chapter in the Bombay district of Poona. She and her group of 'Empire-thinking Indian women' worked mainly in education. ${ }^{17}$ The IODE in Canada raised funds for St Helena's School, of which Sorabji was the principal. In 1930 money was pledged to complete the building of the science block, named 'Canada Wing'. ${ }^{18}$ Such work, however, was very small in scale. The frosty reception that Clark 
Murray's and subsequent Canadian initiative to enact 'Empire unity' met with in Britain served to highlight hierarchies of the Empire that were not supposed to be breached. And, despite being shunned, the IODE continued to celebrate an imagined Britain. Such admiration of Britain was possible because, as Carl Berger argues, imperial ties to Britain were believed to be the way forward for Canadian nationalism. That AngloCeltic settlers were in control of the Dominion of Canada meant that Canada's 'colonial' positioning was very different from the positioning of those deemed 'third world' parts of the Empire. Indeed, the IODE considered itself in a position to extend aid to India.

Patriotic expression was the initial primary objective of the IODE. Formed during wartime, the IODE set out to bolster and support nation and Empire, and all work took place in such a patriotic context that was concerned with citizenship. In this way, the IODE differed from other charitable organizations which did not have patriotism as their primary concern. The IODE's brand of patriotism was often gendered. Engaging with the maternal ideology of care and nurture, patriotism was to be non-partisan and non-sectarian. ${ }^{19}$ Vron Ware writes of the manipulation of women's sexuality to serve imperial ends: 'Whether as Mothers of the Empire or Britannia's Daughters, women were able to symbolize the idea of moral strength that bound the great imperial family together. ${ }^{20}$ In accordance, the IODE's objectives were to stimulate patriotic sentiment, to foster a mind of union among women and children throughout the British Empire, to care for the dependants of military personnel, and to preserve the memory of brave and historic deeds. ${ }^{21}$

Reinforcing its primary patriotic objectives, strong distinctions between patriotism and charity were made clear. In 1905 a national executive meeting was strongly of the opinion that specifically charitable work should not 'direct the energy and funds of the chapters from purely patriotic ends which the Order stood for', and it was recommended that a 'liberal and varied list' of suggestions for active work be published in Echoes, for the benefit of the chapters. ${ }^{22}$ There were guidelines on how work that verged on charity could be made more patriotic. For example, aid given to prevent the spread of tuberculosis should be approached from the patriotic perspective that it was of national concern to maintain a healthy population. ${ }^{23}$ It was suggested that members combine working in hospital wards with reading to patients on imperial topics.

In the formative years fundraising, wherever it was possible, also served patriotic ends. As elsewhere in the Empire, this meant lectures by guest speakers and the production of pageants and plays. John MacKenzie has demonstrated the importance of entertainment in 
fostering imperial attachments in Britain, and in Canada that medium was also used by patriotic organizations such as the IODE. ${ }^{24} \mathrm{~A}$ member in Regina recalls performances given from 'year one' in people's homes and church basements, as well as bazaars and crafts' sales. $^{25}$ Prince Edward Island held a number of notable entertainment fundraisers. In 1913 there was a Kirmess at the Opera House, Charlottetown. The programme included 'A Fate in Fairyland and Pyramid Ballet', chaperoned by Mrs James Warburton, 'The Wood Nymphs', chaperoned by Mrs Bulman, 'A Night in Koko's Garden' from the Mikado, and it ended with the singing of God Save the King. ${ }^{26}$ In keeping with the past, from 1963 to 1971 the Prince Edward Island Chapter staged five popular variety performances called 'Red Glove Reviews'. ${ }^{27}$

The IODE's society connections allowed for some elite entertainment. At the beginning of the twentieth century there were grand balls, which were often held to celebrate imperial holidays. In 1925 the birthday of British Columbia was celebrated at a 'brilliant ball', one of many held in that province. ${ }^{28}$ The ball was hosted by the Lady Douglas Chapter, whose regent for the years 1912-33, Mrs McMiking, had dressed as Queen Victoria at the Victoria Day parade in May 1923, as she did also in $1931 .^{29}$ A member in British Columbia recalls that the IODE was a society 'leader'. Receptions were held for influential Canadians, and when the Hotel Vancouver opened it was the IODE which put on the reception. In 1939, at an empire fete held at the Hotel Georgia in Vancouver, thirty chapters participated under the auspices of the Municipal Chapter of Vancouver. The event was opened by IODE member Mary Bollert, first dean of women at the University of British Columbia. ${ }^{30}$ Bollert was also involved in the Canadian Federation of University Women. Before her appointment at UBC she had administered Sherbourne House Club, Toronto's largest residence for single 'business women and girls', a popular modern hostel that operated according to 'democratic principles of self-management'. ${ }^{31}$

As an organization of female imperialists, the IODE was situated between the mostly male patriotic clubs and the women's organizations. While, in common with the patriotic clubs, the IODE offered imperial lectures and provided opinions on imperial matters, it was also expected to perform maternal work. Unlike male patriotic organizations, which held lectures and offered prizes, from the outset the IODE undertook work. Yet with patriotism came a sense of seriousness, and separation from other women's organizations considered charitable. This view was to persist for many years. Later on in the century, Charlotte Whitton, a prominent and influential long-time IODE member, and Canada's first woman mayor, considered women's auxiliaries to be 'the butterers of bread, the cutters of cake, the brewers of tea, folders of letters, lickers of 
stamps - generally the handmaidens of the social trivialities'. ${ }^{32}$ Whitton was among the policy makers of the IODE, rather than of the membership offering maternal care at ports and courts. She aligned herself with affairs that she considered to be of importance, and believed that women belonged in political leadership. Branded by her biographers a 'feminist on the right', Whitton considered women's progress into the political arena to be motivated by an intent not to alter the system but to improve it. ${ }^{33}$ Her forthright and pragmatic approach found an outlet in the IODE, and generated considerable admiration among the membership. But just as she was an exception and pioneer in her work at the Canadian Council on Child Welfare, and later as the mayor of Ottawa, Whitton was not a 'typical' member of the IODE. The vast majority of members were active in voluntary work in their local communities, serving cake and tea. Meanwhile, Whitton's presence in Ottawa gave the more typical members a voice in the national arena.

To what extent Whitton and other women of strong political opinions used the IODE as a vehicle for their missions is hard to determine. Whitton was the driving force behind the IODE's 1947 study of welfare in Alberta. The IODE's report alleged inadequate and unprofessional child welfare procedures, in particular 'babies for export', the cross-border adoptions of Alberta children. The IODE's allegations led to the 1948-49 Alberta Royal Commission on Child Welfare, which found that the IODE was right in its expression of concern. In this case, the members of the IODE in Alberta had sought the professional advice of Whitton, and collaborated with her in the study. The result was the impressive Royal Commission and a series of recommendations for improvement. ${ }^{34}$

With a clear patriotic mission and an emphasis on citizenship that extended beyond a focus on women and children, the IODE in its initial years fitted only partially with other Canadian women's organizations. Canadian women's historians have written much about the women's club movement of the late nineteenth and early twentieth centuries, the organization of women in different Western countries into collectives dealing with education, culture, philanthropy, reform, politics, professions and religion. ${ }^{35}$ The members of women's clubs have been described by Veronica Strong-Boag as 'largely middle class women who were moved by humanitarian, class and egalitarian concerns to attempt the redemption of society'. ${ }^{36}$ These organizations were a product of a time that saw an ideological distinction between public and private spheres. Thanks to the work of women's historians, we know much about women's maternal role and their place in a constructed 'private' sphere, and of the influence of a 'cult of domesticity'. We know about 
feminist-friendly clubs whose activities were cast as expressions of benevolence or as working towards legislative reform for women's rights. Research on women's Christian societies, such as the YWCA and the Women's Christian Temperance Union (WCTU), has shown the importance to women of moral regulation. Although the impact of class, race and politics was not the primary focus of the study of Canadian women's organizations, their importance has not gone unnoticed. ${ }^{37}$

Because women have for so long been considered marginal to imperialism, it is only now that women's patriotic organizations are receiving in-depth consideration. The IODE is sometimes confused with its southern neighbour, the Daughters of the American Revolution, founded in 1890, which also had patriotism as its central concern. Their similar names, dates of foundation and emphases on patriotism and 'heritage' help to explain the confusion. A key difference, however, keenly felt among the IODE membership, was that the Order's sense of loyalty stemmed from support for Britain; its members' sympathies and in some cases even their blood-lines - derived from the Loyalists who headed for British North America at the time of the American Revolution. The IODE's promotion of connections with Britain has meant that its pragmatic similarities to the Daughters of the Revolution have been downplayed. As I argue in this book, however, the IODE's identity was increasingly situated in North America, and its elite politics, family membership and displays of patriotism were North American. It makes sense, however, to seek similar organizations within the British Commonwealth.

Women's organizations in the British Commonwealth are being read for their contributions to citizenship. ${ }^{38}$ Historians are now turning to women's patriotic organizations' imperialism and its outreach to the white settler colonies, examples of which are the work of Julia Bush on the Girls' Friendly Society, the Primrose League, the British Women's Emigration Association, and Bush and Reidi on the Victoria League. ${ }^{39}$ Bush's latest work, on Edwardian ladies and imperial power, considers how 'the leading ladies of female imperialism sought to impose their gendered, class-bound values upon the national and imperial scene ${ }^{\prime 40}$ As already noted, the Victoria League had intentions of promoting Empire unity that overlapped, as well as clashed with, those of the IODE. The IODE, however, was more 'hands-on' than the Victoria League, working beyond the tea-party and lecture series, seeking to directly influence Canadian citizenship through immigration and canadianization. Here the IODE had much in common with immigration organizations such as the Oversea League, the Girls' Friendly Society, the Salvation Army and the YWCA. These were empire-wide voluntary organizations doing 
much work in the settlement of migrants. As a part of what is sometimes termed 'the women's club movement', the IODE did collaborate with these organizations, but it was also keen to retain its own identity. Where the Victoria League situated itself at the centre of the Empire, the IODE existed to make Canada within the Empire, and attempted to enact its rhetoric through maternal voluntary work.

The IODE also had much in common with other Canadian branches of imperial organizations. Within Canada the IODE was a supporter of the 'evangelical muscular Christianity movements', especially the Girl Guides, that also aimed to create appropriate colonial citizens. ${ }^{41}$ In 1923 the IODE entered into cooperation with the Girl Guides. It did so in the belief that the aims and ideals of both organizations were similar 'as regards a clean, healthy, practical citizenship, based on love of God, King and country ${ }^{\prime 2}{ }^{42}$ With similar objectives and activities to the Girl Guides', junior chapters of the IODE existed sporadically, experiencing strong and weak phases. During the 1950s and 1960s there were teenage chapters for the daughters of members, which held fashion evenings and beauty contests.

It was typical for IODE members to be 'clubswomen', being themselves involved also in several other women's groups at any given time. Indeed, it would have been unusual for a member of the IODE to belong solely to the IODE. IODE members were particularly active in the Canadian Club, various church groups, the Women's Press Club, local and national Councils of Women, various 'heritage' committees, and the Royal Commonwealth Society. The sense emerges, however, that members considered the IODE a unique organization, one that appealed directly to their affiliation as Canadians within the British Empire.

\section{Inventing traditions}

Officially, membership in the IODE was open to 'all women and children in the British Empire or foreign land who hold true allegiance to the British Crown' ${ }^{43}$ The unofficial reality of membership was more restricted, and varied in different provinces and at different times during the century. The social status of patriotic clubs was highest in the preFirst World War years, and the activities and attitudes of the IODE reflected such status. John MacKenzie has written of the turn-of-thecentury patriotic organizations in Britain that 'all of these organizations were middle class and elitist; only one or two enjoyed a wider, more populist membership' ${ }^{44}$ The initial membership of the IODE fits such categorizing. Despite her more general intentions mentioned above, it 
was, after all a Canadian elite which Clark Murray targeted in order to set up initial meetings. It followed that it was the wives of elite males who became the first members.

Out of its elite beginnings, the IODE cultivated its own segregated social hierarchy. Membership was by and large by invitation. There is evidence that potential members, once invited along, were voted in or out through ballot. ${ }^{45}$ In turn, the administrative structure of the IODE developed a hierarchy, best reflected in the structure of the 'Order' itself, which was referred to as a business, a militia, or a parliament where the first members assembled together as first ministers. ${ }^{46}$ In 1916 an IODE publication from Manitoba claimed: 'We like best the definition which calls it [the IODE] a great SISTERHOOD OF SERVICE on which the Empire can rely in war and peace to further all that stands for the betterment of the Race. ${ }^{47}$ The structure of the IODE was the idea of Clark Murray, and has remained largely the same throughout the Order's history. Considered 'simple, but none the less effective' in a 1925 IODE publication, the simplicity came through a series of federated 'levels'. ${ }^{48}$ At the bottom level were the primary chapters, hopefully to be 'in every city and town of the Dominion, and also other parts of the Empire'. ${ }^{49}$ From the outset, an urban geography was a part of the IODE. Primary chapters sent representatives to municipal chapters, which in turn sent representatives to provincial chapters, which in turn fed the national chapter in Toronto. Hence, primary, municipal, provincial and national chapters were the ascending levels of the Order. While individual chapters worked on their own selected projects, there were also projects at the municipal, provincial and national levels. Annual meetings were held at the provincial and national levels. The provincial meetings were usually held in March, in order to give time for proposals to be put before the national meeting held during May. Provincial chapters took turns in hosting the national annual meetings.

The annual national meetings provided the most visible mechanism by which members, spread out over a vast geographic distance, were able to remain united. In an attempt to secure the membership and to make each region feel included, the locus shifted back and forth across Canada. These meetings were held in Canada's grand hotels, such as the York in Toronto, the Beaverbrook in Fredericton, and the Hotel Vancouver. Attending such meetings from afar required considerable funds, and the appropriate attire, including hat and gloves, to meet the formality and the pomp and circumstance of these occasions. The programmes for the meetings displayed much continuity in the format of proceedings. Remembering the war-dead with a march through the streets of the hosting town to lay a wreath at the war memorial was an enduring 
feature of the annual meetings. There was also a service in a Protestant church of one or other denomination. Formal reports were made by the various committees of the Order, at the provincial and national levels, and the president always made a substantial address.

Because the national headquarters was in Toronto, at 182 Lowther Street, in a home donated by the Eaton family, the department-store magnates, the IODE's national presidents have come largely from Toronto, or nearby parts of Ontario. Prior to the Second World War it was not unusual for national presidents to serve for many years. In the postwar period, however, two-year terms became standard. Provincial presidents became vice-presidents of the national chapter of the IODE, also enjoying a two-year term. Like the national presidents, committee secretaries at the national level tended to be from Ontario or the relatively near-by Quebec. The heads of primary and municipal chapters were majestically named 'regents'.

All levels of the IODE were divided into the same committees, each with a secretary. The committees covered services, education, organization, citizenship and Empire study. Each level of the Order also chose a standard bearer for official ceremonies. Before the Second World War the services committee was split into child and family welfare, war and postwar services, and ex-services' personnel. In the post-Second World War years the services committee dealing with war was re-named 'service at home and abroad'. The range of work covered under services included family welfare, cancer clinics, drugs and x-rays, and clothing supplies for Europe and Asia, distributed through the British Save the Children Fund. A percentage of the IODE's service work in the postwar years went outside of Canada. As Chapter eight reveals, the Canadian north became another postwar focus. ${ }^{50}$ After the Second World War, the Empire study committee evolved into the Commonwealth relations committee, $^{51}$ an indicator of the changing times; and the combating Communism and democratic action committees were specifically Cold War innovations. As chapter seven details, these committees were responsible for selecting and sending out articles which were intended for use as study material by the chapters. ${ }^{52}$ Meanwhile, the film committee encouraged the showing of 'suitable' films and British pictures, and urged that matrons be appointed for all children's showings. ${ }^{53}$

Without fail, from its beginnings, the IODE published its own quarterly magazine, Echoes, which was edited by a series of long-serving women journalists, in particular May Kertland and Agnes Mary Pease. As well as reports of the Order's work at all levels, its lavish and professional format included general interest articles, particularly on topics of national and imperial concern. For example, during the 
interwar years there was a series of articles on different parts of the Empire. On the eve of Elizabeth II's coronation in 1953 there was an article by Hamilton IODE member Marjorie Freeman Campbell titled 'Six queens have ruled England' ${ }^{54}$ Current affairs often featured, such as a 1952 article on the Malayan emergency by the national convener of the Empire and world affairs committee, Mrs H. S. Angas. ${ }^{55}$ Such reports of world politics were printed alongside film, fashion, 'kitchen alchemy' and book reviews, written, from the early 1920s into the 1960s, most notably by Wilhelmina Gordon. The sense of community built by Echoes was vital in uniting chapters across Canada.

From the outset, the IODE grew more rapidly in Ontario than elsewhere. Chapters outside of central Canada were boosted by two grand recruitment train trips, one in 1909 to the western provinces, the other in 1910 to the eastern. There was continuity in the membership remaining relatively urban; with membership highest in mediumsized cities such as Regina, Saskatoon or Fredericton, Saint John, Sarnia and London. Anglophone areas such as the eastern townships of Quebec were strongholds, as were former Empire loyalist settlements such as Fredericton, St John, and the region along the Saint Lawrence River in Ontario and Quebec. Overall, membership grew steadily until the First World War, when it peaked at 50,000. That war saw the retention of dominance by the chapters of central Canada as well as the thickening of chapters in the east and west. The huge increase in numbers brought much diversity into the Order, and threatened to swamp the initial membership. This prompted calls by the established elite to change as little as possible. Membership during the interwar years dropped down to 20,000, before receiving a boost to 35,000 during the Second World War. In the postwar years membership has steadily declined, with provincial proportions remaining uniform.

Over the years, Ontario has retained by far the largest membership. British Columbia, Alberta, Nova Scotia and New Brunswick have had memberships of a similar size, with Nova Scotia and New Brunswick declining less in numbers since the Second World War than British Columbia and Alberta. Once on a par with these four provinces, Quebec's membership has declined the most rapidly, with only the chapter in Stanstead remaining. Given the rise of Quebec nationalism, this is perhaps not surprising. Manitoba and Saskatchewan have been next in size, followed by the smaller, but loyal, Prince Edward Island and Newfoundland. The Yukon and the Northwest Territories have had the smallest memberships, but it is significant that the IODE reached, and maintained chapters in, all provinces of Canada. Table 1.1 charts IODE membership, giving provincial proportions for the years for which data 
exist. Membership is currently at approximately 7,000. (I consider the reasons for membership decline in the Conclusion.)

Although officially non-denominational, in reality the IODE was overwhelmingly Protestant, and this Protestant identity was an important component of the IODE's power. One member explains her belief that it was, in equal measure, by choice and chance that at the IODE's beginning it was women from 'rich Protestant Anglo-Saxon families' who had the time to join and that it 'just happened that those were the people who arrived' when the mayors called meetings after receiving Clark Murray's telegram. ${ }^{56}$ All forms of Protestantism were represented, from Anglican to Presbyterian to the United Church of Canada. Although members and written documents insist that denomination was not important, with closed membership there are recollections of excluding and blackballing Catholics. ${ }^{57}$ Judging from the other groups to which members belonged, the leadership in the early years was decidedly Protestant. The IODE's second president, from 1911 to 1919, Mrs A. E. Gooderham, was also the first president of the 1922 Protestant Federation of Patriotic Women. ${ }^{58}$ The divisive potential of such exclusion of other denominations was not missed by the Globe, which declared on March 6 that ' $[\mathrm{t}$ ]olerance, and patriotism, and study of the Empire should be Catholic as well as Protestant qualifications', and that 'a society whose aims are mainly patriotic ought not to start out by excluding more than one-third of the people of Canada'. ${ }^{59}$

What of the diversity of women represented among the IODE membership? Among the IODE's membership were many prominent Canadian women. Their achievements include Canadian 'firsts' for women in many political positions, from Mayor Charlotte Whitton, to Lieutenant-Governor Pauline McGibbon to Federal Government Minister Ellen Fairclough. ${ }^{60}$ As already noted, of particular importance was Charlotte Whitton, professional welfare worker, social commentator and first woman mayor of Ottawa, who kept the IODE up to date on welfare and educational issues, formed IODE policy and used the IODE as a platform for her beliefs. Among the membership were many respected educators, including Wilhelmina Gordon, first woman lecturer at Queen's University, and Mary Bollert, first dean of women at the University of British Columbia, both of whom used their expertise to execute the IODE War Memorial Scholarships. ${ }^{61}$ Indeed, if there were prominent Canadian women who were not themselves members of the IODE, then there were strong connections to them among the membership. This was also the case with elite Canadian families, such as the Eatons and Gooderhams. Although the Order became increasingly non-elitist as the century progressed, class distinctions remained. 


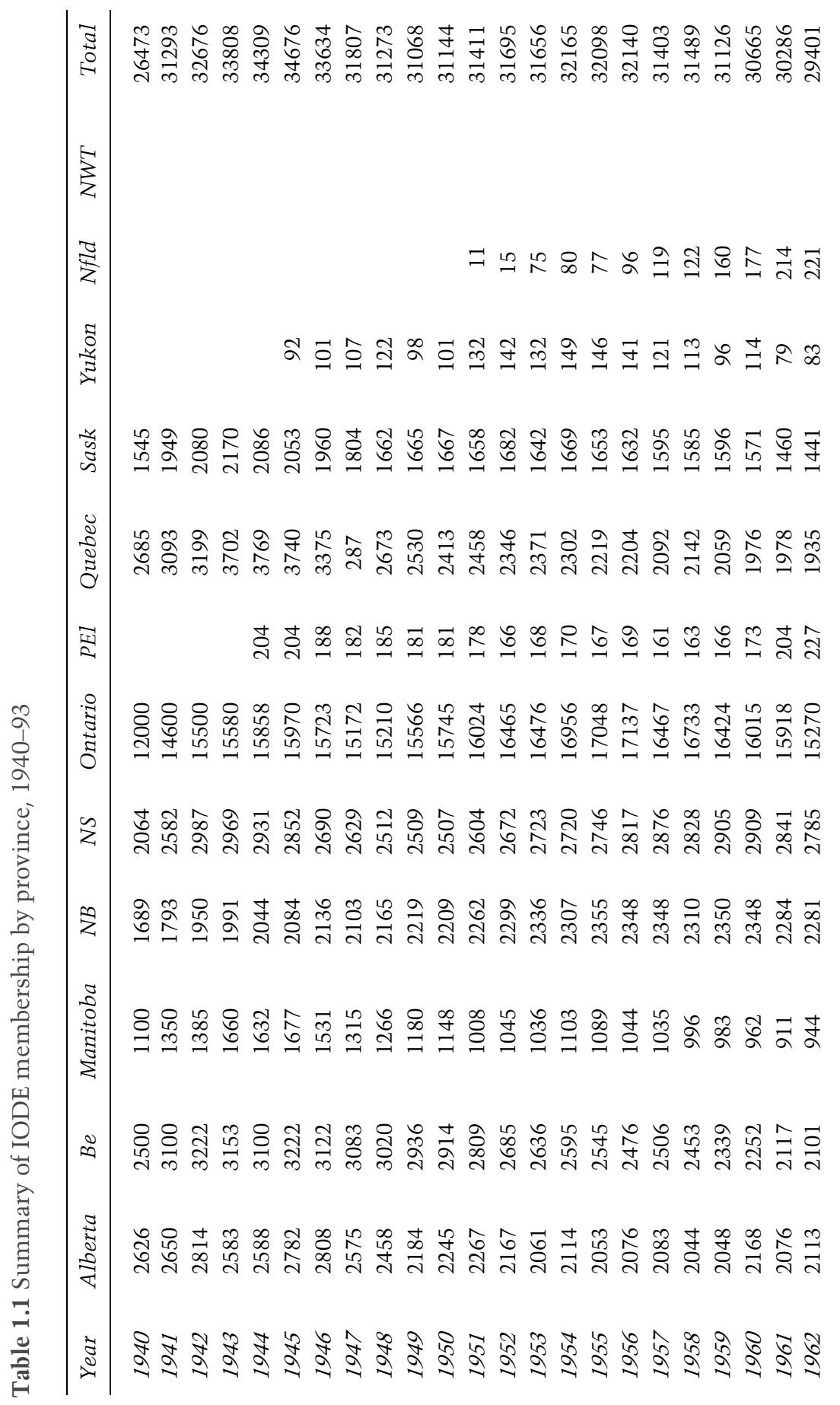




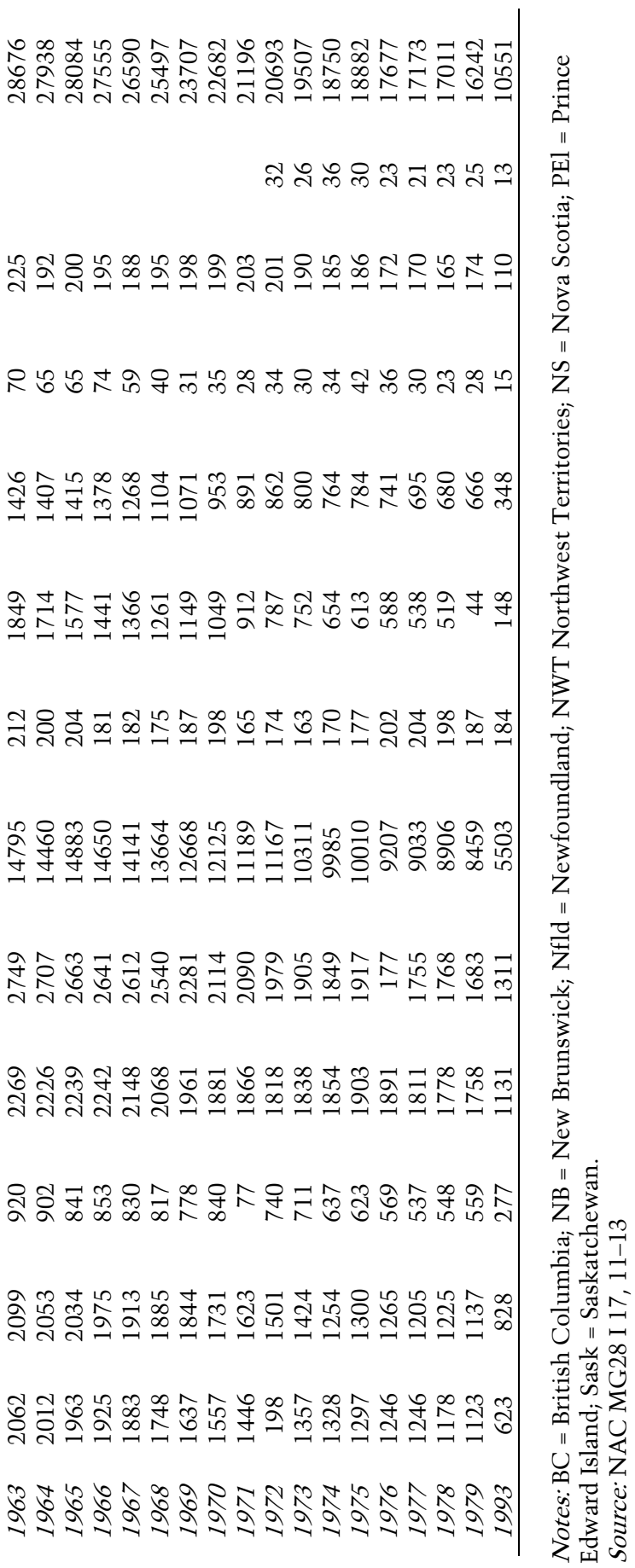


A leading post-Second World War example of a revered long-time member was Pauline McGibbon, IODE national president from 1963 to 1965. McGibbon was the British Commonwealth's first woman lieutenant-governor (1974-81) serving as the queen's representative in Ontario. McGibbon was, among her other achievements, the first woman chancellor of the University of Toronto (1971-74). In some ways her life started out like many other Canadian women's. Born in Sarnia, Ontario, McGibbon did well at school, where she met her future husband Don McGibbon. In 1932 Don took a job with Imperial Oil Ltd, a company within which he would rise to become vice-president and treasurer. Soon after her marriage to Don in 1935, Pauline McGibbon joined the IODE and helped to found a new chapter. ${ }^{62}$ She then embarked on a life of community service. Pauline McGibbon was a member of many clubs, including the Canadian Club, the Empire Club, the Ladies' Club of Toronto, the volunteers' committee of the Art Gallery of Ontario, as well as being involved in supporting the performing arts. ${ }^{63}$ With no children, and with no need to be in paid employment due to the support of her husband, Pauline McGibbon was able to devote time to her voluntary work. While in many ways her lifestyle had much in common with earlier, Edwardian, IODE members, at a time of secondwave feminism she was able to reach positions of leadership previously reserved for men.

Despite the changing class composition that accompanied the growth in numbers, there was an overall continuity in IODE membership formed from family and social networks. The Anglo-Celtic Canadian membership, defined in terms of the Anglo-Canadian identity that the IODE has promoted, still dominates. A member in Regina defends her background, against the snobbish treatment she received from the Victoria League in London:

And I have quite the background. I think that I can stand up with the best of them. I'm very proud of the fact that my grandfather came out to this area at 16 years old in 1882, and his mother followed the next year as a widow with eight children - and homesteaded and got her land claim in her name. Grandpa was mayor of Regina twice. There are several buildings named after him in Regina. He was a very prominent person, a lawyer. The other side of my family, my mother's side, have been here from 1912 on. Grandpa was an entrepreneur, very active in the church and Masons and things like that, very involved, but a farmer, that too. We're all very basic people. And I myself have been honoured to have received several awards, volunteer awards and what have you, and I've been very involved in heritage. ${ }^{64}$

As Cecilia Morgan has shown in the placing of Laura Secord within the narratives of Canadian loyalist history, this telling of family history 
evokes memory and tradition when calling for inclusion in the 'imagined community' of Canada. ${ }^{65}$ It is a pioneering narrative of ordinary people succeeding in an egalitarian society.

'Daughters of the Empire' was intended by Clark Murray to capture the symbolic connection of women through the Empire, but over the years the name also took on literal meaning and has contributed to the longevity of the Order. There is much evidence of inter-generational family membership of the IODE, with family networks particularly evident among members in national positions. Members are often wellaware of their family's history in the IODE. A Toronto member recalls: 'My mother was in it, a life member of Toronto, Ontario and national. I grew up with it and then joined in 1976. ${ }^{166}$ Another member says that she was 'born into IODE'. Her grandmother was a member in Regina, her mother was national president and her daughter is a fourth-generation IODE member. ${ }^{67}$

Joining the IODE after marriage, invited by her new mother-in-law, was a frequent practice that has made many a member literally a 'daughter'. A Toronto member joined in the late 1950s when her motherin-law's chapter, which had been together since before the First World War, was looking for new members. They took in a group of younger members and became a two-level chapter, 'which was not entirely successful, because we were all so polite and nice, and didn't say "Sit down, mother, and be quiet, we're going to do it this way'" ${ }^{\prime 68}$ In eastern Ontario a member was invited by her mother-in-law to join the IODE soon after she was married: 'It had closed membership at that time. We had seventy people in the chapter, and you had to wait your turn. ${ }^{69}$ Another member, in British Columbia, joined just before her marriage. Her sister-in-law to be, who lived in west Vancouver, called her to see if she was interested in joining a new chapter that was forming. ${ }^{70}$ A Regina member's great-aunt had been a provincial president and was happy to hear that her relative had joined: 'She was so pleased when I went up and told her that I had joined IODE, and she didn't have any family of her own, so I had made her day. ${ }^{71}$

Local chapter names are a fascinating testament to the IODE's quest to assimilate difference into the dominant narrative of Anglo-Canada. The chapters illustrate Edward Said's assertion that 'the power to narrate or block other narratives from forming and emerging ... is very important to culture and imperialism and constitutes one of the main connections between them'. ${ }^{72}$ In the chapters' names there is an employment of diverse traditions, drawing upon people, places and achievements that all come together in support of Anglo-Canadian identity. ${ }^{73}$ Some names celebrate famous men, often war heroes, usually 
from Britain. Other names were taken from the geographical area in which the chapter met, or from the regiment with which the chapter was associated. Among the chapter names in British Columbia in 1953 were Captain Cook, the British explorer and hero; Ruskin, the British philosopher of aesthetic anti-modernism; Canadian Scottish; Unknown Warrior; Memorial Silver Cross, for wartime self-sacrifice; and Kitsilano and Kerrisdale, after two Vancouver suburbs. ${ }^{74}$ Chapters were sometimes named after women. There was the Emily Carr Chapter in British Columbia, named for the painter, and the Pauline Johnson Chapter named for the native Canadian poet. In an annual ceremony members placed daffodils, her favourite flower, on her monument in Stanley Park, and then took tea. ${ }^{75}$ In their promotion of Anglo-Canadian identity, chapter names evoked a sense of idealism, of a romantic chivalry that extended to the dramatic idea of being a Daughter of the Empire whose badge was a seven-pointed star. Such anti-modernism is not surprising given the salience of such sentiments within Canadian imperialism of the turn of the century period. Naming chapters after literary figures and glorious imperial and Canadian figures endorsed the promotion of a strongly British Canada.

The IODE's way of dealing with diversified and marginal groups as its members was containment within distinct chapters. Local chapters acted as local containers of identity, especially where non-Protestant and non-Anglo-Celtic members were concerned. Such chapters at once served to emphasize the possibilities of assimilation into the Canadian mainstream, yet were containers of religion, such as the Catholic chapters in Quebec; containers of ethnicity, such as the Jon Sigurdsson Chapter of Winnipeg, made up of Icelandic immigrants, the Saint Margaret of Scotland Chapter of Alberta, made up of Hungarian immigrants ${ }^{76}$ and the Native Chapter in British Columbia; or containers of class, such as the First World War blue-collar Ross Rifles Chapter, chapters of nurses, ${ }^{77}$ the professional women's Elizabeth Tudor Chapter in Ottawa during the $1930 \mathrm{~s}^{78}$ and military chapters, in which members were through their husbands attached to specific regiments, such as the Argyle IVth in Belleville, Ontario, or the RCMP Scarlets in Regina. Chapters also segregated along occupational, ethnic, religious and age lines for pragmatic reasons. Particular meeting times, as well as areas of expertise, suited chapters of teachers, and chapters of Catholics and Jews found camaraderie from meeting with women of the same religion amid a predominantly Protestant Order.

The structure of the IODE provides an insight into the workings of an organization that has by a long stretch outlived the Empire that it was formed to defend. Much of the IODE's strength was found within its structure, its stable organizational hierarchy and its ability to swing into 
action. Family networks played a big part in keeping membership alive from generation to generation, and also contributed to continuity in the social composition of membership. Although the women who belonged to the IODE were the very women likely to belong to other women's organizations, there was a sense of joining the IODE for life, and that members saw the Order as an outlet for their sense of imperial and national identity. The IODE's structure also reflected its vision for Anglo-Canada. Early chapter names displayed the formation of an AngloCanadian identity constructed from British influences. As the century progressed, more local heroes and heroines appeared in chapter names. The dominant narrative was ever-changing, and appeared more encompassing, yet the assumption of assimilation was not abandoned. Rather, the organizing principles of the early years of the century were re-presented.

\section{Notes}

1 Benedict Anderson, Imagined Communities: Reflections on the Origin and Spread of Nationalism, 2nd edn (London and New York: Verso, 1991), 142.

2 NAC MG28 I 17, 18, 3, 11a, 13 Feb 1900, At Windsor Hotel parlours, Montreal.

3 Interview, 25 February 1994: Toronto, Ontario.

4 Carl Berger, The Sense of Power: Studies in the Ideas of Canadian Imperialism, 18671914 (Toronto: University of Toronto Press, 1970).

5 Carman Miller, Painting the Map Red: Canada and the South African War 1899-1902 (Montreal and Kingston: McGill-Queen's University Press, 1993). Miller is a past IODE War Memorial Scholar.

6 Julia Bush, Edwardian Ladies and Imperial Power (Leicester: Leicester University Press, 2000). This is an argument also made by Elizabeth L. Riedi in her PhD thesis, 'Imperialist women in Edwardian Britain: the Victoria League 1899-1914', PhD thesis, St Andrew's University, 1998.

7 Margaret Poison Murray, 'The Order: its past and its future. By the founder', NAC MG28 I 17, Misc. files, document 4; Clark Murray was also known as Poison Murray.

8 W. David McIntyre, The Significance of Commonwealth, 1965-90 (Basingstoke and London: Macmillan, 1991).

9 John M. MacKenzie, Propaganda and Empire: The Manipulation of British Public Opinion, 1880-1960 (Manchester: Manchester University Press, 1984), 148.

10 Ibid., 150.

11 Provincial Archives of New Brunswick (hereafter PANB), MC 200 MS 1/A/1.

12 NAC MG28 I 17, 18, 3, 3 and 12.

13 NAC MG28 I 17, 11, 1902-4.

14 Poison [Clark] Murray, 'The Order: its past and its future', 2.

15 Margaret Gillett, 'Growing pains: Mrs Murray, Lady Minto, Mrs Nordheimer and the early years of the IODE', Address to the James McGill Society, Montreal, 24 January 2000, 2-3.

16 IODE, 'A brief history 1900-1958', 1. Document housed at IODE national headquarters in Toronto.

17 Ibid., 2.

18 Ibid. 
19 NAC MG28 I 17, 2, 2 Feb. 1911.

20 Vron Ware, Beyond the Pale: White Women, Racism and History (London and New York: Verso, 1992), 162.

21 Pamphlet (IODE, 1982).

22 NAC MG28 I 17, 16 March 1905.

23 NAC MG28 I 17, 4 October 1905.

24 MacKenzie, Propaganda and Empire.

25 Interview, 18 April 1994: Regina, Saskatchewan.

26 Public Archives and Records Office, Prince Edward Island (hereafter PARO, PEI], Acc. 3995, 7, Souvenir programme for 18-20 December 1913.

27 Interview, 27 October 1993: Charlottetown, Prince Edward Island.

28 Vancouver City Archives (hereafter VCA), NI/IM/ 7L, 1, Scrapbook of Lady Douglas Chapter 1919-39: 'Lady Douglas Chapter IODE hosts annual function'.

29 VCA, reel \#0286 IODE, 24.

30 VCA, Publications, 99, 25 November 1939, Empire fete, ballroom and lounge, Hotel Georgia, Vancouver Municipal Chapter.

31 Carolyn Strange, Toronto's Girl Problem: The Perils and Pleasures of the City 18801930 (Toronto: University of Toronto Press, 1995), 178-85.

32 P. T. Rooke and R. L. Schnell, No Bleeding Heart: Charlotte Whitton, a Feminist on the Right (Vancouver: University of British Columbia Press, 1987), 211.

33 Ibid.

34 NAC MG20 E 256, vol. 34, IODE Province of Alberta, 'Report on a report', 1949; Echoes (summer 1947), 'Welfare study in Alberta', 7.

35 Veronica Strong-Boag, The Parliament of Women: The National Council of Women in Canada 1893-1929 (Ottawa: National Museums of Canada, 1976), 2. See also Prentice et al., Canadian Women.

36 Strong-Boag, Parliament of Women, vii.

37 See Barbara Roberts, "A work of Empire": Canadian reformers and British female immigration', in Linda Kealey (ed.), A Not Unreasonable Claim (Toronto: Women's Press, 1979), 185-202.

38 See Fiona Paisley, Loving Protection! Australian Feminism and Aboriginal Women's Rights, 1919-39 (Carlton South: Melbourne University Press, 2000); Fiona Paisley, 'Citizens of their world: Australian feminism and indigenous rights in the international context, 1920s and 1930s', Feminist Review, 58: spring (1998), 66-84; and Angela Woollacott, 'Inventing Commonwealth and Pan-Pacific feminism: Australian women's internationalist activism in the 1920s-30s', Gender and History, 10:3(1998), 425-48.

39 Julia Bush, 'Edwardian ladies and the "race" dimensions of British imperialism', Women's Studies International Forum, 21: 3 (1998), 277-89; and see Bush, Edwardian Ladies and Imperial Power; and Reidi, 'Imperialist women in Edwardian Britain'.

40 Bush, Edwardian Ladies and Imperial Power, 13.

41 MacKenzie, Propaganda and Empire, 243.

42 National Library of Canada (hereafter NLC), The Imperial Order Daughters of the Empire 1900-1925 (IODE, 1925), 30.

43 NAC MG28 I 17, 2, 6 November 1912.

44 MacKenzie, Propaganda and Empire, 148.

45 British Columbia Archives and Records Service (hereafter BCARS), Add. MS 255, 3, Emily Carr Chapter Minutebook 1960-70. Membership was by ballot, and majority vote.

46 Interview, 24 April 1994: Calgary, Alberta.

47 Royal Commonwealth Society Library, London (hereafter RCSL), IODE, Manitoba Souvenir, 1916. 


\section{GENEALOGY}

48 IODE 1900-1925, 5.

49 Ibid.

50 IODE, 'A brief history 1900-58', 4.

51 Ibid., 3.

52 Ibid., 4.

53 Ibid.

54 Marjorie Freeman Campbell, 'Six queens have ruled England', Echoes (summer 1953), 3 and 19.

55 Mrs H. S. Angus, 'The war in Malaya', Echoes (Christmas 1952), 7.

56 Interview, 25 October 1993: Saint John, New Brunswick.

57 Interview, 26 October 1993: Charlottetown, Prince Edward Island; interview, 27 August 1995. Stanstead, Quebec.

58 Hopkins, J. Castell, The Canadian Annual Review of Public Affairs (Toronto: Annual Review Publishing Co., 1922), 392.

59 Ibid.

60 For the life of Pauline McGibbon, see Norma West Linder and Hope Morritt, Pauline: A Warm Look at Ontario Lieutenant-Governor Pauline McGibbon (Sarnia: River City Press, 1979); for Charlotte Whitton, see Rooke and Schnell, No Bleeding Heart; and for Wilhelmina Gordon, see David G. Dewar, Queen's Profiles (Kingston, Ontario: Office of Endowment and Public Relations of Queen's University, 1951).

61 See Katie Pickles, 'Colonial counterparts: the first academic women in Anglo-Canada, New Zealand and Australia', Women's History Review, 10: 2 (2001), 273-97.

62 West Linder and Morritt, Pauline, 71.

63 Ibid., 120.

64 Interview, 18 April 1994: Regina, Saskatchewan.

65 Cecilia Morgan, "'Of slender frame and delicate appearance"', 103-19, at 115.

66 Second interview, 24 February 1994: Toronto, Ontario.

67 Interview, 4 November 1993: Ottawa, Ontario.

68 Interview, 25 February 1994: Toronto, Ontario.

69 Interview, 9 October 1993: Campbellford, Ontario.

70 Interview, 29 April 1994: Vancouver, British Columbia.

71 Interview, 18 April 1994: Regina, Saskatchewan.

72 Edward Said, Culture and Imperialism (London: Virago, 1993), xiii.

73 See Eric Hobsbawn and Terence Ranger (eds), The Invention of Tradition (Cambridge, Melbourne and London: Cambridge University Press, 1983).

74 VCA, Vancouver and Municipal Chapter Records, Chapter highlights, 1952-53.

75 VCA, Matthews Collection, 'IODE honors Indian poetess', 18 March 1946. See Veronica Strong-Boag and Carole Gerson, Paddling Her Own Canoe: The Times and Texts of E. Pauline Johnson (Tekahionwake) (Toronto: University of Toronto Press, 2000).

76 Interview, 29 April 1994: Vancouver, British Columbia; and second interview, 24 February 1994: Toronto, Ontario.

77 Echoes, 68 (June 1917), 89.

78 Lorne Pierce Special Collections, Queen's University (hereafter LPSC), IODE, Ottawa Souvenir, 1935. 